\title{
当院での核医学検查施行後に発生する 放射性医療廃臬物の取扱いマニュアルの紹介
}

\author{
木田哲生・井口治巳・野間和夫 \\ 吉村雅寛・濱津尚就・増田一孝
}

2002年9月6日

2003年 $2^{\text {論文受理 }}$

滋賀医科大学医学部附属病院放射線部

Code No. 633

\section{諸 言}

核医学検查を受けられた患者より発生するオムツ等 感染性医療廃衰物を病院等加廃衰処分される時点 で，その廃亲物より放射線が検出されることか問題と なって以来，核医学検査施設で，その管理方法につい て苦慮されている。

この問題に対して核医学関連 5 団体より平成 12 年 9 月に作成，各施設に配布された「放射性医薬品を投与. された患者の才ムツ等の取扱いについて」では，その 注意点と適切な管理の必要性を示し，また平成13年 4 月には「放射性医薬品老投与した患者のオムツ等の取 扱いについて」のガイドライン，取扱いマニュアルが 学会雑誌に揭載され，具体的な管理方法について広く 示されだ、しかしながら，このガイドライン，取扱 いマニュアルにもあるように，関係者のコンセンサス を得たうえで，施設状況に合わせた管理手順での対応 の必要がある。施設ごとに有効な管理方法を以て，そ
の取扱いがなされていくべきであると考える。

さらに，平成13年 3 月に厚生労働省医薬安全局長名 で通知された「医療法施行規則の一部を改正する省令 の施行規則」(医薬発第188号)では，一診療用放射性同 位元素を投与された患者に伴う固体状の污染物につい ては，適切な放射線測定器を用いて测定することによ り放射線管理に関する適切な取扱いを行うこと一と唱 われている。この局長通知は曖昧ではあるが，従来よ り誤って解釈されていた，核医学検查を受けた患者か ら発生する排泄物等の放射線が検出される廃棄物に対 して，その適切な管理の必要性を法的に示している。 この状況からすべての施設で行われなければならない と判断する。

今回，当院で約 1 年間，運用してきた核医学検査施 行後に発生する感染性医療廃亲物の取扱いについての 管理運用マニュアルを紹介する。

な㧍，このマニュアルは，事務系職員，看護部，放

\section{Introduction of Manual for the Management Radioactive Medical Waste}

\section{TETSUO KIDA, HARUMI IGUCHI, KAZUO NOMA, MASAHIRO YOSHIMURA, MASANARI HAMAZU, and KAZUTAKA MASUDA}

\author{
Department of Radiology, Shiga University of Medical Science \\ Received Sept. 6, 2002; Revision accepted Feb. 1, 2003; Code No. 633
}

\section{Summary}

Societies concerned with radioactive rays and nuclear medicine have recently highlighted the necessity of managing radioactive medical waste resulting from nuclear medicine examinations. We introduce a manual that we have created and explain its use in decision-making and management practices aimed at the reduction of radioactive medical waste at hospitals that have not yet solved this problem. We hope that our manual will help in reducing this medical waste.

Key words: Radioactive medical waste 
射線部，各診療科の数回の議論，意見交換の結果，作 成された素案を基に作成し，当院放射線安全委員会で の承認を得，放射線安全委員会が発行した。そして， このマニュアルに準じた管理方法の实施は，病院長命 にて要請したものであり，その锥限を有する。

〈放射性医薬品を投与された患者さんから発生する オムツ等あるいは医療廃棄物の取扱いマ二ュアル〉

管理運朋マニュアル日次をTable 1に示す. 以下，本 文を示す。

\section{1. 本マニュアルの目的}

「廃妄物処理及び清掃に関する法律」では，放射性物 質および放射性物質により污染されたものは集何対象 から除外されています。そのため放射性医眢品を投与. された患者さんのオムツ等あるいは医療廃亲物から放 射線が检出されますと産業廃萊物采者に引き取りを拒 否されます。

そして国民に核医学諩療に対古る䛊解と不安を与え ないように医療現場に拈ける放射線安全管理を徹底す る必要があります。

これは核医学検査至単独では，徹底することは困難 であり，監師，看護スタッフの協打のうえに成立する ものであります。その具体的な方法を示すことにより 当院から放射線が検出される医療廃栾物を出さないよ う管理することを本マニュアルの目的とします。

\section{2. 当院における管理概要}

(1) 管理とは

ここでいう「管理」とは，放射性物質により浱染され た可能性がある廃菓物を放射性同位元䋕の減衰によ り，バックグラウンドレベルになるまで待ち，一定期 間，保管することです。号らにその間，他の廃亲物に 混ぜて廃轰されることを防止することです。

(2)当院に拈ける管理厅法

当院での方法は，あらかじめ，核医学検查を施行し た患者さんを把握することにより，各病棟，各診療科 の外来診察公, 中央診療施設 [乎術部, 集中治療部 (C.C.U.を含む)，放射線部，検査部，透析部](以下， 病棟等) で発生古る放射性医薬品により活染された才 ムツ等や医療廃衰物 (以下, 該当廃亲物)の管理対象廃 案物を集中化させ，それを明確にする方法です。

核医学検査を施行された患者さんの把握には，核医 学検䍒空から発行される「核医学検查施行通知」を用い ます。保管管理を必要とする期間が明記されています ので，カルテに添付することにより，情報伝详の碓実 性を四ります。そして検査時あるいは緊急手術等の不 測の事態に抢いても，患者さんに同行した管理を可能
Table 1 Index of the manual.

1. 本マニュアルの目的

2. 当院での管理概要

(1) 管理とは

（2）当院における管理方法

3. 管理の対象となる廃棄物の種類

4. 管理が必要な日数

5. 検査依頼時の留意事項

(1) 核医学検査を予約するとき

(2) 核医学検査を行った後,転棟,手術,処置,血管造影,人工透析を 依頼するとき

6. 核医学検査室での留意事項および手順

(1)「核医学検査施行 通知」作成

（2）患者さんへの説明

7. 検査終了以後の保管管理の手順および注意事項

(1) 該当廃棄物発生から院外廃棄までのフローチャート

(2)病棟等での取扱い手順および注意事項

(3) 核医学検査室での取扱い手順および注意事項

(4) 病院地下集積場での取扱い手順および注意事項

8. 廃㶳物の放射線測定の実際
(1) 測定者
(2) 測定方法
(3) 測定結果の記録

9. 放射性廃棄物管理業務に伴う放射線の影響

10. おわりに

とすることができます。

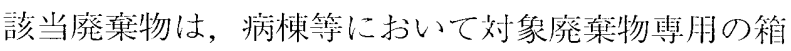
あるいは容器に集中させることにより，その数量を少

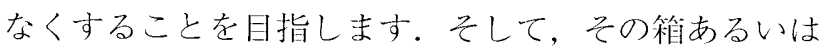
容器には, 廃卒可能日を記載した該当廃會物であるこ とを示古「廃菓可能日表記ステッカ一」を貼付し，保管 管理が必要であることを明確に表示します。

そして，最終的に廃集物回収業者に引き取りを依頼 する際に，そのすべての廃较物を対象に放射線測定を 行い，規䇥值以下のものを廃葉します。

\section{3. 管理の対象となる廃棄物の種類}

放射性物質により活染された可能性がある該当廃葉 物にはTable 2に示すようなものがあります。

その他, 核医学検查を行った後, 大量に体液が付着 したものについても, 放射線が検出されることも考え られます。

\section{4. 管理が必要な日数}

核医学検查に使用する放射性医輩品(放射性同位元 素)の種類で，管理が必要な日数は異なります。その 日数の目安をTable 3に示します。

なお，保管日数が経過した後でも，放射線が検出さ れることもあるため，院外に廃辣するときには必ず， 
Table 2 Kinds of wastes for management.

\begin{tabular}{|c|c|}
\hline 発生箇所 & 放射線が検出される可能性がある廃棄物例 \\
\hline 各病棟, ICU & 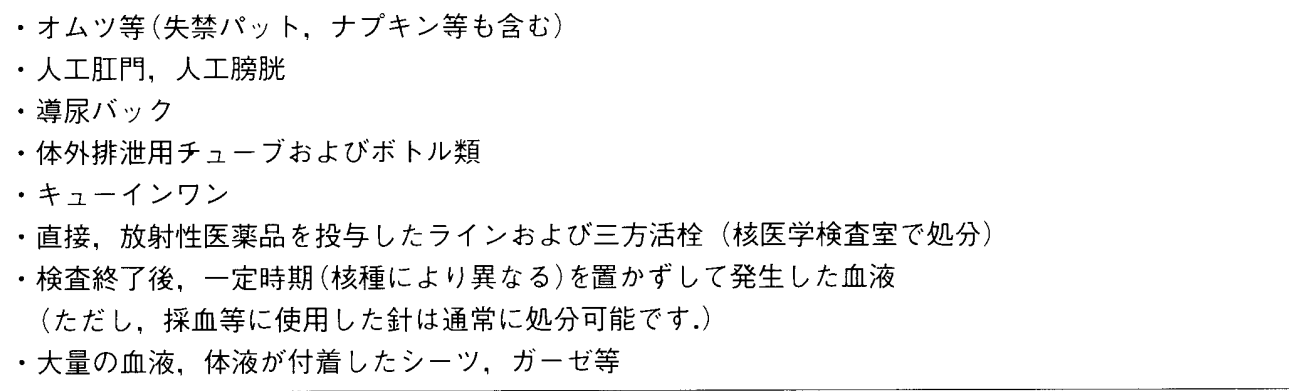 \\
\hline $\begin{array}{l}\text { 手術部(IVMRIを含む), } \\
\text { 透析部 }\end{array}$ & $\begin{array}{l}\text { ・検査終了後, 一定時期(核種により異なる)を置かずして行われた血管造影および手術等により } \\
\text { 発生した血液, 大量の血液が付着したシーツ, ガーゼ等 } \\
\text { (ただし, 採血等に使用した針は通常に処分可能です.) } \\
\text { ・検査終了後, 一定時期(核種により異なる)を置かずして行われた人工透析後の廃液の凝固されたもの }\end{array}$ \\
\hline 放射線部，核医学検査室 & $\begin{array}{l}\text { ・体外排泄用チューブおよびボトル類 } \\
\text { ・検査終了後, 一定時期(核種により異なる)を置かずして行われた血管造影および処置等により発生し } \\
\text { た血液, 血液が付着したジッ, ガーゼ等 }\end{array}$ \\
\hline
\end{tabular}

Table 3 Main examinations and days required for safekeeping.

\begin{tabular}{|c|c|c|c|c|}
\hline コード & 検査名 & 使用放射性同位元素名 & 物理的半減期 & 管理日数 \\
\hline 1 & ガリウムシンチ & $\mathrm{Ga}-67$ & $78 \mathrm{hr}$ & 10日 \\
\hline 2 & 胆道シンチ & Tc-99m & $6 \mathrm{hr}$ & 2 日 \\
\hline 4 & 肝・脾シンチ & Tc-99m & $6 \mathrm{hr}$ & 2 日 \\
\hline 47 & 肝機能シンチ (Tc-99m GSA) & Tc-99m & $6 \mathrm{hr}$ & 2 日 \\
\hline 5 & 甲状腺 (I-123) & $1-123$ & $13 \mathrm{hr}$ & 3 日 \\
\hline 6 & 甲状腺 (TI-201) & TI-201 & $73 \mathrm{hr}$ & 10日 \\
\hline 7 & 甲状腺 (Tc-99m) & Tc-99m & $6 \mathrm{hr}$ & 2 日 \\
\hline 25 & 耳下腺·顎下腺·唾液腺 & Tc-99m & $6 \mathrm{hr}$ & 2 日 \\
\hline 8 & 動的腎シンチ & Tc-99m & $6 \mathrm{hr}$ & 2 日 \\
\hline 9 & 腎シンチ & Tc-99m & $6 \mathrm{hr}$ & 2 日 \\
\hline 11 & 脳血流 (1-123 IMP) & $\mathrm{I}-123$ & $13 \mathrm{hr}$ & 3 日 \\
\hline 48 & 脳血流 (Tc-HMPAO) & Tc-99m & $6 \mathrm{hr}$ & 2 日 \\
\hline 49 & 脳血流 (Tc-ECD) & Tc-99m & $6 \mathrm{hr}$ & 2 日 \\
\hline 46 & 脳血流 (Xe ガス) & $\mathrm{Xe}-133$ & $5.2 \mathrm{~d}$ & 必要なし \\
\hline 54 & 脳TIシチチ & TI-201 & $73 \mathrm{hr}$ & 10日 \\
\hline 12 & 骨シンチ & Tc-99m & $6 \mathrm{hr}$ & 2 日 \\
\hline 24 & 脳槽・脊髄腔シンチ & $\ln -111$ & $68 \mathrm{hr}$ & 10日 \\
\hline 26 & 骨髄シンチ & $\ln -111$ & $68 \mathrm{hr}$ & 10日 \\
\hline 18 & 心プール & Tc-99m & $6 \mathrm{hr}$ & 2 日 \\
\hline 44 & 心血流シンチ (TI-201)（安静） & TI-201 & $73 \mathrm{hr}$ & 10日 \\
\hline 16 & 心血流シンチ（TI-201）（負荷） & TI-201 & $73 \mathrm{hr}$ & 10日 \\
\hline 50 & 心血流シンチ(Tc-MIBI) & Tc-99m & $6 \mathrm{hr}$ & 2 日 \\
\hline 51 & 心血流シンチ(Tc-Tetrofosmin) & Tc-99m & $6 \mathrm{hr}$ & 2 日 \\
\hline 52 & 心筋脂肪酸代謝 (I-123-BMIPP) & $1-123$ & $13 \mathrm{hr}$ & 3 日 \\
\hline 53 & 心筋交感神経 (I-123-MIBG) & $1-123$ & $13 \mathrm{hr}$ & 3 日 \\
\hline 57 & RIアンギオ & Tc-99m & $6 \mathrm{hr}$ & 2 日 \\
\hline 14 & RIベノグラフィ+肺シンチ & Tc-99m & $6 \mathrm{hr}$ & 2 日 \\
\hline 19 & 肺血流分布 (MAA) & Tc-99m & $6 \mathrm{hr}$ & 2 日 \\
\hline 20 & 肺エロゾル換気 & Tc-99m & $6 \mathrm{hr}$ & 2 日 \\
\hline 22 & 肺機能 $(K r-81 m)$ 換気・血流 & $\mathrm{Kr}-81 \mathrm{~m}$ & $13 \mathrm{~s}$ & 必要なし \\
\hline 27 & 副腎皮質 (1-131 アドステロール) & $\mathrm{I}-131$ & $8 d$ & 15日 \\
\hline 41 & 副腎髄質（I-131 MIBG） & $\mid-131$ & $8 d$ & 15日 \\
\hline 34 & メッケル咊室シンチ & Tc-99m & $6 \mathrm{hr}$ & 2 日 \\
\hline 45 & 腸管血行動態シンチ & Tc-99m & $6 \mathrm{hr}$ & 2 日 \\
\hline 60 & タリウム腫瘍シンチ & TI-201 & $73 \mathrm{hr}$ & 10日 \\
\hline 59 & 消化管出血シンチ & Tc-99m & $6 \mathrm{hr}$ & 2 日 \\
\hline
\end{tabular}


放射線の測定が必要です。

\section{5. 検直依頼時の留意事項}

ここでは特に，医師(主治医)が，核医学検査を依頼 する場合，あるいは，検查後の一定期問(管理が必要 な日数) 以内に手術, 検查, 処置, 透析等の予定(緊急 も含む)があり，該当廃褒物が発生する招それのある 場合の留意事項を示します。

\section{(1) 核医学検査を予約するとき}

1)主治医は，核医学検查をオーダする際，その時点 で判明している以下のことを「検査目的と実施上 の指示」の欄に記載下さい。

・便排泄にオムツ等を使用

・導尿パック等体外排泄に関する医療器具を使用

・手術予定日

・血管造影実施予定日

- 人工透析実施予定日

2)患者の診断，治潦に支障のないことを前提に，管 理が必要な医療廃弃物が発生する抢それがある患 者さんの核医学検查は，短半減期のTc-99m製刜 を用いた検査に変更して下さることを要望しま す。（例えば，TI-201，123-I製剤を用いた検査を Tc-99m製剂へ)

(2)核㘣学検查を行った後，転棟，手術，处置，血管 造影，人工透析を依頼するとき

核医学検查を行った後，管理を要する期間内に転 科，転棟の事態が生じた場合，あるいは手術，処置， I血管造影，人工透析を依頼されるときには，

・核医学検查を行った日付

·使用核種

・管理に要する保管期間

手術申込書，検查依頼票，透析指示溥に記し，依頼

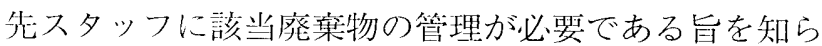
せて下さい。

\section{6. 検㚗当日の留意事項および手順}

(1)「核医学検查施行 通知」作成

1) 検查前日

検查前日の検查担当者は，翌日検査予定入院患 者分の検相内容のチェックおよび放射性医薬品の 発注を行い, そして「核医学検査施行 通知」の出 力を行います (Fig. 1，2).

2) 検査当日

検查当日の朝，検查室にカルテ到着時に，カル テの所定の䇢所に「核医学検查施行通知」を添何 します (Fig. 3)。

(2) 患者さんへの説明

患者さんが核医学検查室に来室されたとき，該当廃
（検查前日）

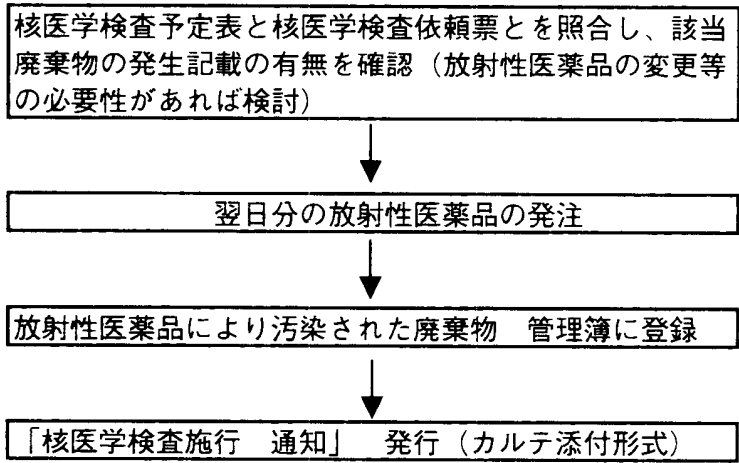

（検査当日）

カルテの所定の位置に「核医学検查施行 通知」を添付

Fig. 1 Procedures to be followed the day before examination and on examination day.

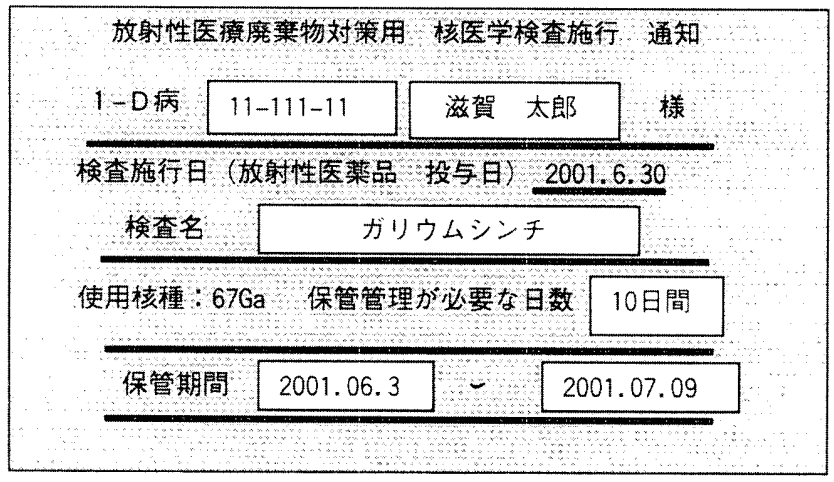

Fig. 2 Nuclear medicine examination enforcement notice to be pasted on patients' records.

案物が発生することが明らかな場合には，患者さんあ るいは家族に対して，それらが一定期間，廃裹できな いこと，保管管理の必要性を説明して下さい.

\section{7. 検査終了(検査㩰投与)以後の保管管理手順および 注意事項}

(1) 該当廃菓物発生から院外廃童までのフローチャー 卜

検查薬投与㖟より発生した該当廃葉物は該当廃亩物 発生から院外廃育までのフローチャートに従って廃案 されます (Fig. 4).

該当廃案物の発生の確認は，娭査当日，カルテに添 付される「核医学検查施行通知」により行って下さ い.

(2) 病棟等での取扱い手順捛よび注意事項

カルテに添付してある「核医学検查施行 通知にによ

り，患者さんから発生する廃裹物の保管管理の必要性 


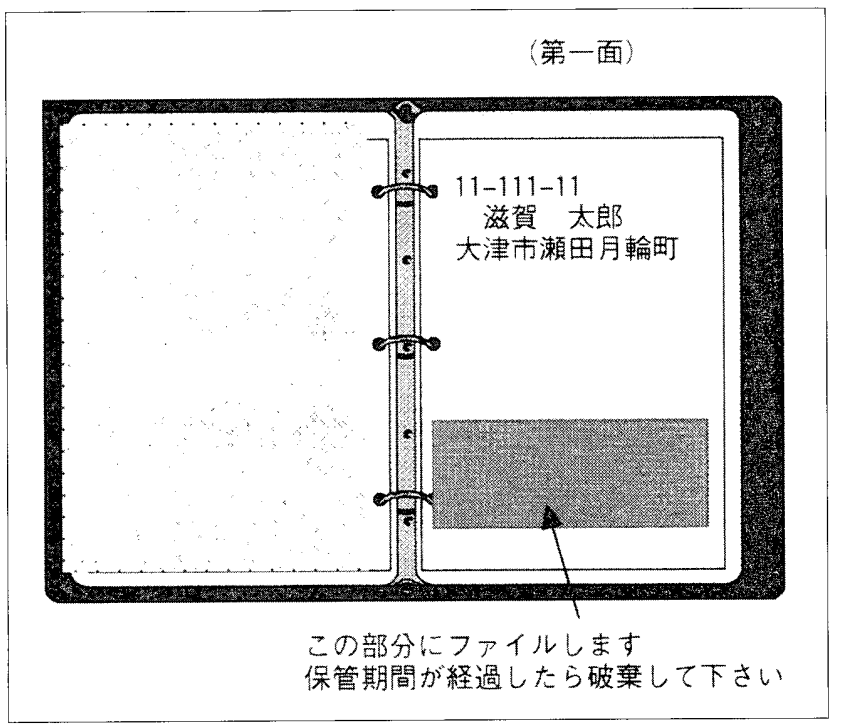

Fig. 3 Place to paste notice tags.

の有無を病棟スタッフ間で確認して下さい。あらかじ め, 病棟等で該当廃亲物保管管理場所を決定しておい て下さい.

病棟等での取扱いは病棟等での取扱いフローチャー

卜に従って行って下さい(Fig. 5，6).

な扔，「核医学検查施行 通知」はそれに記載のある 期間を過ぎたとには，速やかに破棄して下さい。

【注意事項】

1)必ず手袋を着用して下さい。

2)病棟等から廃妄する際には，「廃裹可能日表記又 テッカー」とは別途, 従来ど扔りの廃菓日, 発生 場所，廃案作業者名を記載して下さい。

3)不明な点，対処に困ったときは核医学検査室まで 問い合わせ, 相談して下さい。（核医学検查室電 話番号)

(3) 核医学検査室での取扱い手順掞よび注意事項

核医学模查公廃秉保管室に回仪，保管管理が必要と 判断した場合，以下の手順で保管管理して下さい(Fig. 7).

\section{【注意事項】}

1)必ず手袋を着用して下さい。

2)感染性溌案物には十分注意して下さい。

3) 測定は廃亲保管室外のB.G.が低い場所で行って下 さい.

(4)特別管理産業廃率物集積場での取扱い手順および 注意事項

特別管理産業廃率物集積場から廃亲物回収業者に引 き渡される廃案物はすべて放射線測定し，規定值未満 であることを確認しなくてはなりません（Fig. 8).

放射線量が規定值以上でさらに保管管理が必要な該 当廃亲物を一時保管するスペース (保管管理エリア)を

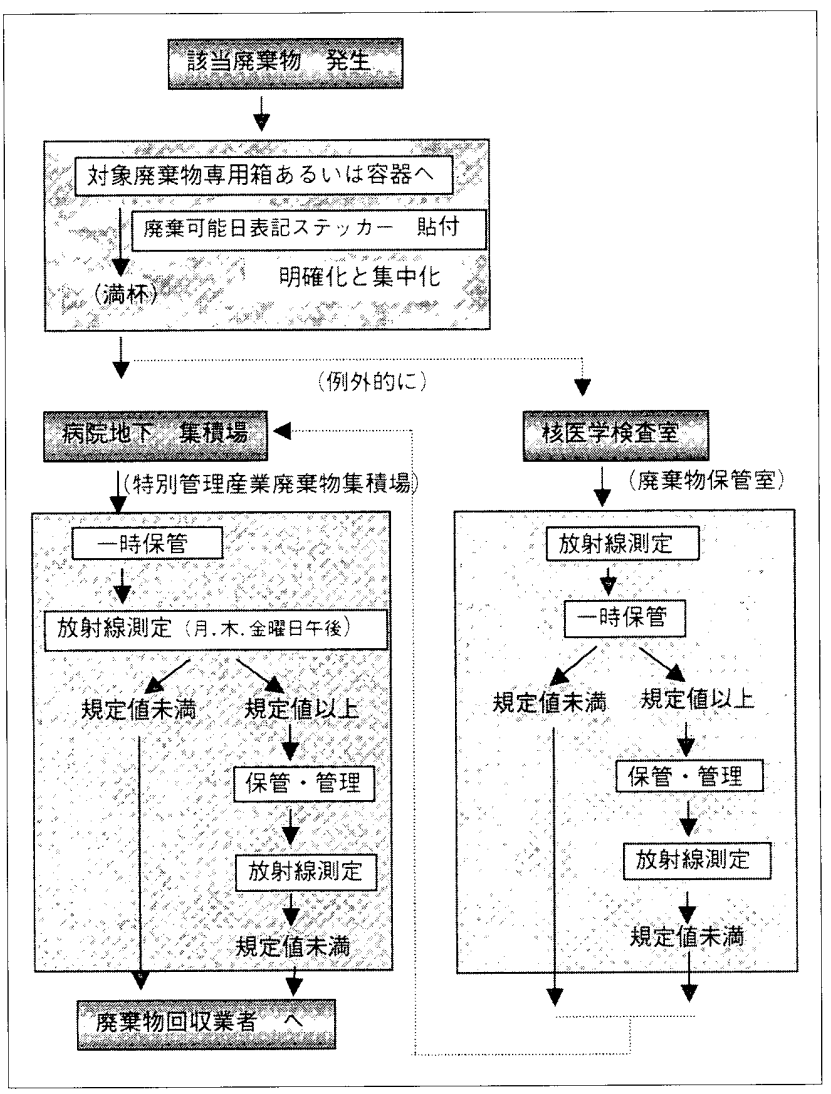

Fig. 4 Flowchart of management.

設けて下さい.

測定対象廃棄物；

・「廃叟可能日表記ステッカー」が貼付されていない 廃萧物

・「廃童叮能日表記ステッカー」が㙋付かつ発菓川能 日を経過した廃楀物

測定日；院外廃案日の午前

【注意事項】

1)必ず手袋を着用して下さい.

2)感染性廃案物には十分注意してドさい。

\section{8. 廃芼物の放射線測定の実際}

集積場に集まった該当廃妄物を産業廃杗物回収業者 に引き渡す前に行う，あるいは核医学検査窒に持ち込 まれた廃亲物の廃裹前に行う放射線测定の方法を示し ます。

(1)放射線測定者等

(測定実務者)

特別管理産業廃暂物集積場 (病院地下)

………..メンテナンス業者

核医学検査室 核医学検查担当者 （測定日）

特別管理產業廃葉物集積場 …院外廃率日 午前 核医学検查室 ……………………随時 (適時) 


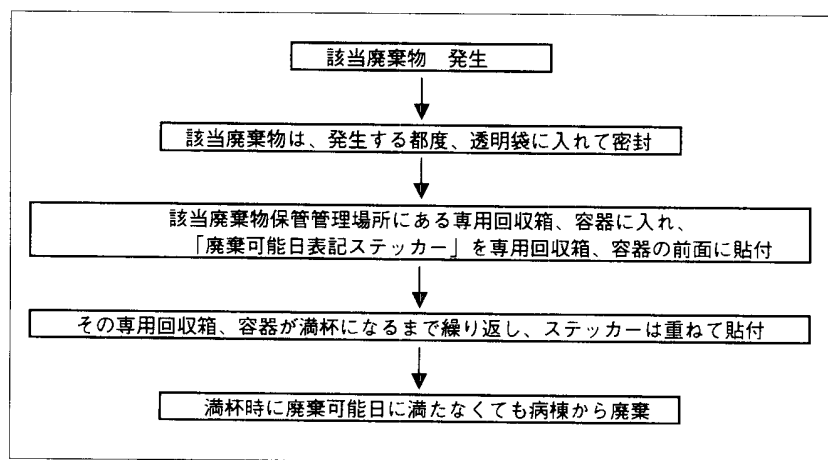

Fig. 5 Flowchart of management in wards.

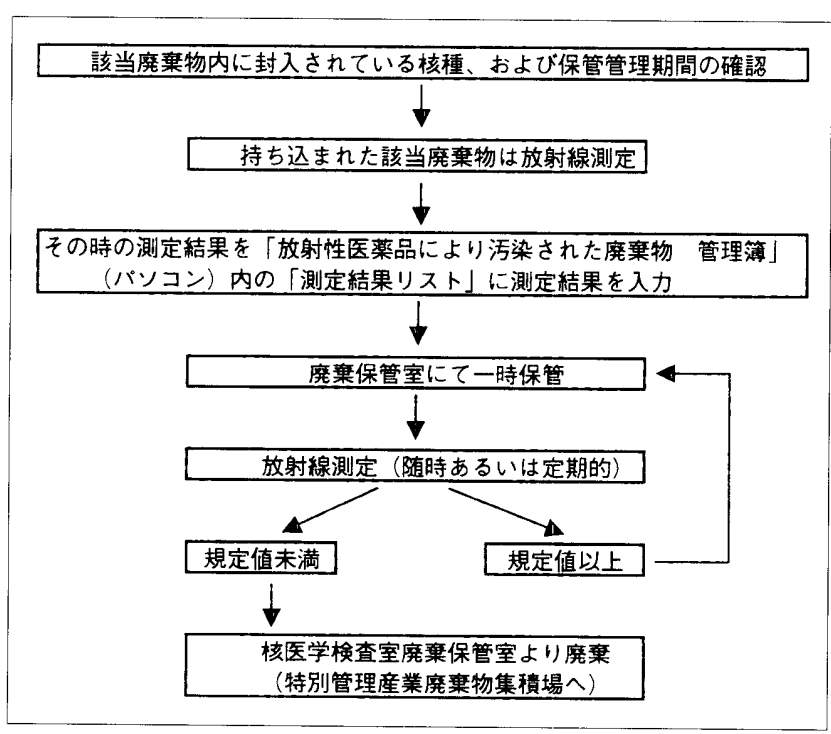

Fig. 7 Flowchart of management in examination room.

(測定器)

病院地下 特別管理産業廃棄物集積場

........Aloka PDR-101

核医学検查室 Aloka PDR-101 TGS-136

(2) 測定方法

1)バックグラウンド (B.G.)の測定

(1)測定は周辺に廃棄物等がないところで行って下 さい.

(2)測定時間は30秒程度行って下さい.

2)対象廃棄物の測定

(1)測定を行う廃充物は，他の廃亲物より 2 メート ル以上離して下さい。

(2)測定は底面を除く5面を行って下さい。

(3)一測定面に対して廃棄物容器の表面を，数回走 査して下さい.

(4)B.G.值以上のものはさらに保管管理が必要で す.

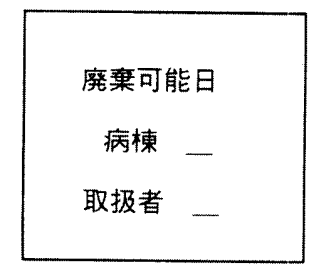

廃棄可能日表記ステッカー (黄色)

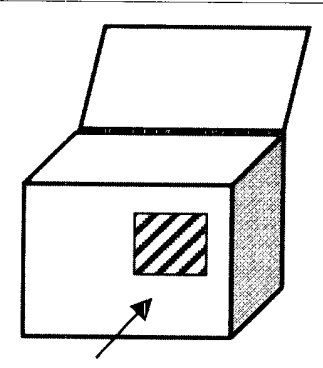

ここに（重ねて）

貼付
*「廃棄可能日表記ステッカー」は病院一階防災監視室前廊下 に用意しています。

Fig. 6 Place to paste stickers on waste boxes to show disposal day.

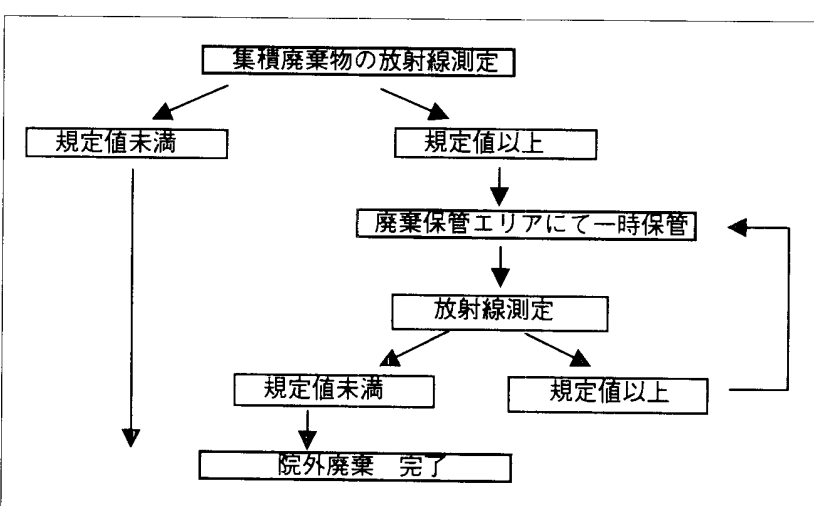

Fig. 8 Flowchart of management in places of waste accumulation.

3)測定結果の記録

(特別管理産業廃棄物集積場での測定結果)

最終的に院外への廃棄が完了する際には「院外 廃棄時における医療廃裹物放射線測定記録」にそ の測定結果等を記録して下さい(Fig. 9).

また，極度に強い放射線を検出したとき，該当 廃亲物の取扱いに不備があったときには核医学検 査室まで連絡して下さい.

\section{9. 放射性廃重物管理叢務に伴う放射線の影響}

放射性廃杗物の取扱い時㧍よび保管管理中の廃妄物 からの放射線被曝は微量であり，その量は多く見積も つても自然放射線 ( $2.4 \mathrm{mSv} /$ 年)の数日一 10 日分程度で あると推定されています。したがって放射性廃棄物か らの放射線の影響はなく，たとえ取扱い者，廃棄作業 者が妊娠されていても心配ありませんり。

\section{0. おわりに}

放射性医療廃妄物が当院から発生することがないよ 


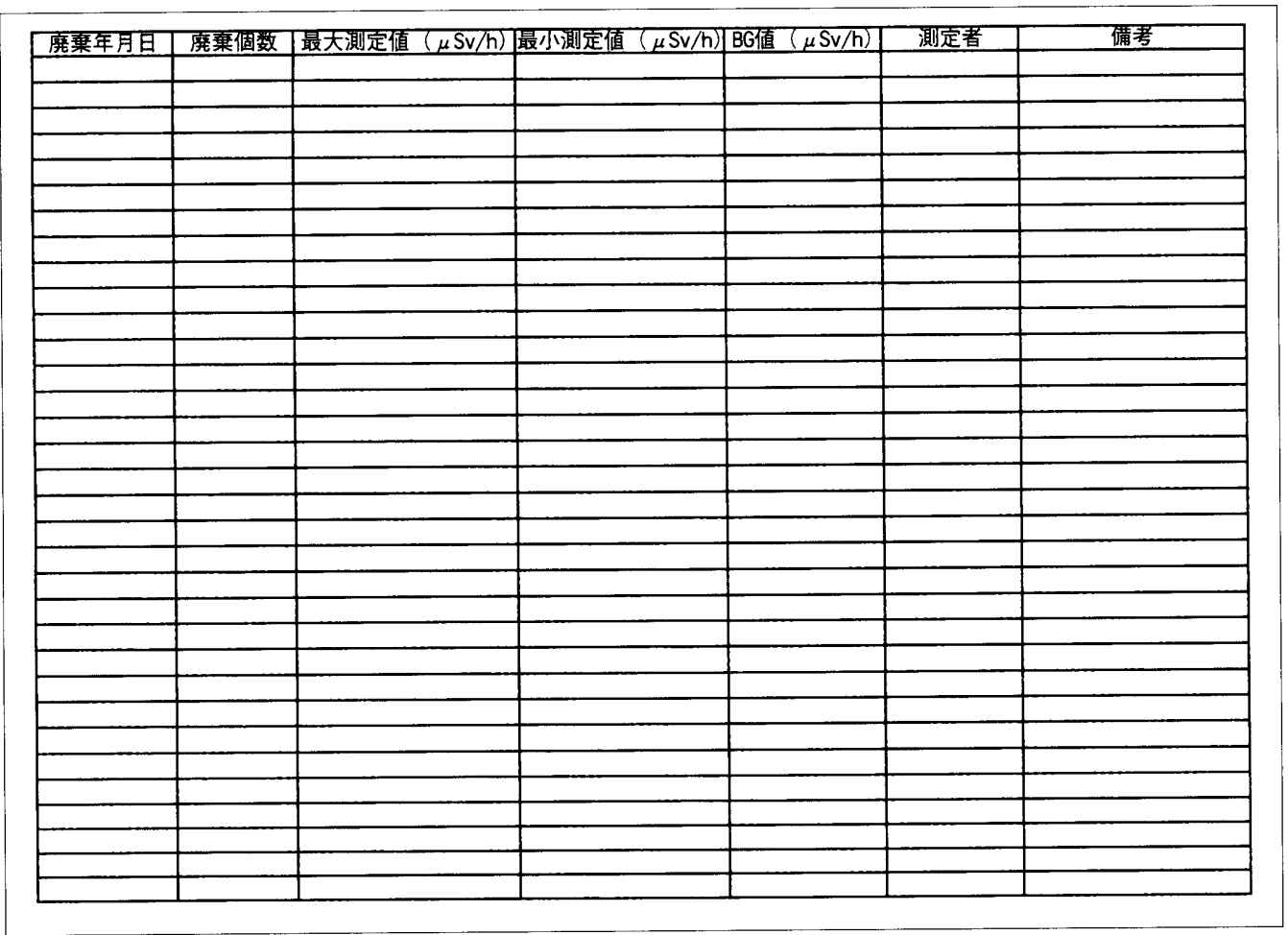

Fig. 9 Figure of measure record of radioactive rays contain into medical wastes at carry out hospital.

うに管理処理システムを整備する必要があり，このマ ニュアルを作成しました。

本マニュアルでの詳細は, 次の基本概念のうえに成 立しています。

1)核医学検査は比較的低侵襲で有効な検査法であり,

このマニュアルが核医学検査を妨げるものではない こと.

2)核医学検査を受けられた患者さんの人権を脅かすも のではないこと.

3)廃棄物の管理は，被曝管理が主の目的ではなく，廃 棄物から発生する放射線を管理することが目的であ ること.

4)職員相互の協力により成立し, 効果的な管理ができ ること.

以上が管理マニュアルの本文である。

(当マニュアルに対する考察)

当院での管理方法に集中管理方式を根底においた個 別管理併用方式をとる理由には，

1)病院全体としての問題意識を持つ

2)特定の職員の負担を軽減する

3) 核医学検査への理解と適切利用

としており，核医学検査担当者および廃率物の放射線 测定者のみが行う管理方式では他職種の協力が得られ にくい，連用が形式だけとなる可能性を回避し，患者
にかかわる職員が理解し，業務の分散を図ったもので ある、

当院ではすべての廃棄物に搬出者の責任を明確にす るため搬出者氏名，日時を記載することが義務付けら れており，当マニュアルの運用導入時には，いくつか の問い合わせ以外に混乱はなく，比較的スムーズであ つた。看護師長会での説明会以外に看護師に対する特 別な説明会は行わなかったが，要請があればその目 的，詳細に関寸る説明会は必要であろう。そして核医 学検査従事者は, 院内で最もその運用を理解し, 問題 発生，問い合わせには対応しなければならない。

院外廃棄時には放射線湘定を行っているので, 診療 科病棟等で運用に遺漏があっても問題ないが，継続的 に発生したときは申し入れを行い修正を促している。

マニュアルによる管理運用して 1 年経過しての現状 の把握, 職員の理解度, 問題点を確認することも必要 と考える。

\section{おわりに}

この管理運用マニュアルの作成に協力いただいた職 員，実際の運用に協力いただいている職員の皆様に感 謝の意を表する。

また，当管理運用マニュアルが，今後，この問題に 取り組まれる施設の参考となれば幸いである。 


\section{参考文献}

1) 核医学分科会・放射線防護分科会：分科会報告 放射性医 学誌, 57(5), 543-549, (2000).

薬品を投与した患者のオムツ等の取扱いについて．日放技

\section{図表の説明}

Fig. 1 核医学検査室での検査施行前日おうよび当日の手順

Fig. 2 核医学検査施行通知 様式

Fig. 3 核医学検查施行通知 添付箇所

Fig. 4 該当廃亲物発生から院外廃棄までのフローチャート

Fig. 5 病棟等での取扱いフローチャート

Fig. 6 廃棄可能日表記ステッカーおよび貼付場所

Fig. 7 核医学検査室での保管管理フローチャート

Fig. 8 特別管理産業廃棄物集積場での保管管理フローチャート

Fig. 9 院外廃弱時に抢ける医療廃裹物放射線測定記録 様式

Table 1 マニュアルの目次

Table 2 管理対象廃棄物例

Table 3 主要核医学検査に㧍ける放射性(医療)廃棄物の保管管理に必要な日数 